\author{
Janusz Mariański \\ Wyższa Szkoła Nauk Społecznych z siedzibą w Lublinie \\ (D) https://orcid.org/0000-0002-0620-8000
}

\title{
Odrodzenie moralne społeczeństwa polskiego w refleksji socjologicznej Jana Szczepańskiego
}

\begin{abstract}
In this study, Janusz Mariański first presents selected themes from the works of Jan Szczepański, the great representative of Polish sociological thought. These themes include: the moral condition of Polish society (the concept of man and society, the morality of public life, economy and work ethos, manifestations of moral evil, suffering) and moral revival as an idea and reality, with particular emphasis on the issues of individuality. On the basis of these findings, Mariański formulates some general conclusions regarding moral transformations in Polish society and a proposal for changes conducive to moral revival (moral reform, a revitalization of morality, moral education).
\end{abstract}

Key words: the concept of man and society, the morality of public life, the economy and work ethos, manifestations of moral evil, moral revival

Współczesne społeczeństwa, niezależnie czy nazwiemy je nowoczesnymi czy ponowoczesnymi, niosą ze sobą określone szanse i niebezpieczeństwa dla wartości, zwłaszcza o charakterze uniwersalnym. Nie są one końcowym stadium historii ludzkości, ani idyllicznym rajem, ani nieuchronną apokalipsą. Między rajem i apokalipsą będą istnieć zawsze realne społeczeństwa ze swoimi problemami, dylematami, konfliktami, ale i z wizją lepszej przyszłości, którą trzeba świadomie i odpowiedzialnie kształtować. Teraźniejszość i przyszłość nie jest czymś wyznaczonym z góry i deterministycznie określonym. Należy wyrazić nadzieję, że potencjał wspólnych wartości nie został jeszcze zużyty i jest możliwa jego rewitalizacja w społeczeństwach współczesnych. 
W życiu publicznym, a zwłaszcza politycznym, potrzebne jest odrodzenie moralne czy nawet swoista rewolucja moralna. Zbyt wiele jest korupcji, działań „na skróty”, klientelizmu, kłamstwa, „bezinteresownej” nieżyczliwości itp. Potrzebny jest namysł nad tym, co nas łączy i co nas dzieli, do czego prowadzi to, co dzieje się aktualnie, do czego doszliśmy dzisiaj. Czy odchodzenie od trwałych wartości moralnych do zmiennych opcji tworzących swoiste uniwersum liberalne jest pod każdym względem procesem pożądanym, prowadzącym we właściwym kierunku? Według jakich kryteriów podejmować tzw. racjonalne decyzje, skoro wybrane rozstrzygnięcia odpowiadają jednym, są zaś odrzucane przez innych (Mariański, 2008b, s. 60-68)?

Wiedza socjologiczna ma tylko prawdopodobny charakter, a socjologia nie wypowie wszystkiego i do końca o moralnej kondycji społeczeństwa. Jej diagnozy nie powinny być jednak niedostrzegane czy tym bardziej ignorowane. W perspektywie socjologicznej możemy opisać zjawiska i procesy moralne w społeczeństwie, wskazać ich genezę, mechanizmy rozwojowe, konsekwencje społeczne itp., pokazać, jak działają wartości i normy moralne w określonym kontekście społeczno-kulturowym, ale nie potrafimy postawić ważnych z etycznego punktu widzenia pytań o jakość analizowanych zjawisk, ich sens, pożądany kierunek przemian. Możemy jednak przyjąć, że moralność na miarę godności i wielkości człowieka to coś więcej niż zwykły produkt (konstrukt) zmiennych wartości społeczno-kulturowych. Wyznacza ją jakaś ,prawda” moralna oparta na naturze ludzkiej, którą socjolog może określić bardziej intuicyjnie niż w precyzyjnych kategoriach teoretycznych.

Socjologia nie interesuje się wprost istnieniem absolutnych wartości i norm moralnych, niezależnych od zmiennych poglądów i okoliczności życia jednostkowego i społecznego. Prawdą jest, że socjologowie znacznie częściej ukazują przejawy ich zmienności niż trwałości, że z reguły wskazują na zróżnicowanie ocen i norm oraz zachowań moralnych w zależności od warunków historycznych i społeczno-kulturowych. Socjologia - podkreślając empiryczną relatywność czy pluralizm moralności - ukazuje tylko część prawdy o człowieku, o jego kondycji moralnej i duchowej. Różnorodność wartości i norm, jaką opisuje ta empiryczna nauka o moralności, nie stoi $\mathrm{w}$ sprzeczności z przekonaniem o istnieniu norm i wartości moralnych o charakterze absolutnym, chociaż zależnych od środowiska społeczno-kulturowego. Zmusza jedynie do refleksji nad nieadekwatnością naszego ujmowania wartości i norm moralnych oraz przyczynia się do głębszego i bardziej krytycznego sprecyzowania w wielu sprawach tradycyjnej problematyki moralnej. Pośrednio jest także wołaniem o przeciwdziałanie relatywizmowi moralnemu, który stał się częścią naszej codziennej wyobraźni i problematyki życiowej.

Socjologia nie jest jedyną interpretatorką życia moralnego. Takie rozwiązanie oznaczałoby konieczność przejęcia przez nią funkcji historii, psychologii, pedagogiki, filozofii i teologii, co byłoby swoistym absurdem. Interpretowanie moralności w świetle tylko jednej z nauk byłoby wyraźnym redukcjonizmem. Należy także podkreślić zasadę ustawicznej zmienności w socjologii. Jej ustalenia nie są nigdy 184 ostateczne, często mają poniekąd przybliżony charakter i mogą być udoskonalane. 
Różnice w postrzeganiu i wyjaśnianiu zjawisk społeczno-moralnych nie muszą być wynikiem interesów czy uprzedzeń osób prowadzących badania empiryczne. Nie można też oczekiwać od socjologa moralności zbyt wiele. Nie jest on w stanie odpowiedzieć na wszystkie oczekiwania społeczne. Socjologia ukazuje, jak moralność jest praktykowana w życiu codziennym, nie wskazuje zaś na to, jaka moralność powinna być akceptowana. Normatywne kryteria, według których jest wartościowane społeczeństwo, nie mogą być do końca socjologicznie uzasadniane. We współczesnej socjologii moralności utrwaliło się przekonanie, że socjolog odkrywa pewne prawidłowości społeczne (prawa) o charakterze etycznym, które nie mają mocy obowiązującej. Także teorie socjologiczne wyjaśniają rzeczywistość, ale jej nie normują (Mariański, 2005, s. 53-82).

Socjologia przyczyniła się do zrozumienia, w jak wielkim stopniu poznanie ludzkie jest względne i zależne od okoliczności. „Przedmiotem socjologii jest badanie wpływu środowiska na człowieka i określa ona stopien, w jakim człowiek zależny jest od środowiska" (Leclercq, 1964, s. 216). Socjologia uprawiana w perspektywie personalistycznej usiłuje pokazać człowieka nie tylko jako „wytwór” społeczeństwa, ale i opisać jego wpływ na społeczeństwo, pozwala postawić pytania o wartości bezwzględne związane z godnością osobową człowieka i o kryteria kształtowania dobrego społeczeństwa. Można także zapytać: co powinien robić socjolog w warunkach pogłębiającej się dekonstrukcji moralności prywatnej i publicznej? Czy może dostarczyć wartościom i normom moralnym socjologicznej legitymizacji?

W niniejszym opracowaniu prezentujemy najpierw wybrane wątki z prac klasyka polskiej socjologii Jana Szczepańskiego dotyczące zagadnień moralnych, takich jak: kondycja moralna społeczeństwa polskiego (koncepcja człowieka i społeczeństwa, moralność życia publicznego, gospodarka i etos pracy, przejawy zła moralnego, cierpienie) oraz odrodzenie moralne jako idea i rzeczywistość, ze szczególnym uwzględnieniem problematyki indywidualności. Na kanwie tych ustaleń spróbujemy sformułować kilka ogólnych wniosków dotyczących przemian moralnych w społeczeństwie polskim oraz propozycję zmian w kierunku odrodzenia moralnego (reforma moralna, rewitalizacja moralności, wychowanie moralne).

\section{Kondycja moralna społeczeństwa polskiego w pismach Jana Szczepańskiego}

W naukach społecznych są prowadzone badania nad rzeczywistymi zjawiskami oraz procesami zachodzącymi w różnych grupach społecznych i w całym społeczeństwie, które dostarczają danych empirycznych o zespołach działań ludzkich, kwalifikowanych jako moralne lub niemoralne. W sensie pozytywnym moralnością nazywa się te zespoły zachowań ludzkich, które odpowiadają uznawanym 
kryteriom dobra i doskonałości w sensie etycznym. Człowiek postępujący zgodnie z tymi kryteriami jest zazwyczaj oceniany pozytywnie. W codziennej praktyce każdy człowiek staje jednak często przed wyborem: albo osiągnie i zrealizuje swoje cele życiowe i aspiracje, naruszając w mniejszym lub większym stopniu ustalone nakazy etyki, lub też będzie przestrzegał zasad etyki, a ceną za to będzie poniesienie strat w realizacji własnych celów (Szczepański, 1980, s. 7).

W życiu społecznym najważniejsze jest to, co dzieje się między ludźmi, to, co ich łączy w zbiorowości społeczne. Życie społeczne - stwierdza Szczepański - jest zespołem zjawisk zachodzących między ludźmi. Dlatego też cechy ludzi wzajemnie na siebie oddziałujących nie mogą być obojętne dla badaczy społecznych, w tym i socjologów. Chodzi tu o coś więcej niż tylko o przemijające cechy i zmienne ich kombinacje - przede wszystkim o pewne podstawowe właściwości człowieka decydujące o nim lub też stanowiące jego człowieczeństwo, naturę ludzką, wyznaczającą w sposób trwały zachowania ludzkie. Wielu socjologów i przedstawicieli innych nauk o człowieku, zajmujących się życiem społecznym, sądzi, że natura ludzka jest wielkością stałą, działającą zawsze jednakowo, a zatem w badaniu zachowań społecznych ludzi możemy się nią nie interesować, a skupiać uwagę tylko na elementach społecznych i kulturowych. Inni uważają, że istnienie takiej gatunkowej natury ludzkiej jest niezbędnym warunkiem prawidłowości przebiegu życia społecznego i dlatego jej poznanie i uwzględnienie w badaniach to konieczność (Szczepański, 1970, s. 104-105, 158; Sztompka, 2017, s. 94-97).

Według Szczepańskiego należy diagnozować kondycję społeczną, polityczną, kulturalną, moralną i gospodarczą społeczeństwa, formułować programy działania i działać (Szczepański, 1982, s. 337-345; 1986b, s. 3-7; 1987a; 1989b, s. 4—5, 17; 1992b, s. 11-108).

W obszernym biogramie Szczepańskiego, zamieszczonym w Encyklopedii socjologii, Jolanta Kulpińska omówiła najważniejsze kierunki zainteresowań badawczych tego socjologa. Wymieniła m.in. takie zagadnienia, jak: przemiany w strukturze społeczeństwa polskiego (makrostruktura społeczna), przemiany w warstwie inteligencji i na wsi, industrializacja i jej skutki społeczne, przemiany w konsumpcji i systemie wartości, edukacja i oświata, rozważania nad losem człowieka. Ta ostatnia problematyka dominowała w twórczości Szczepańskiego w latach 80. i 90. XX wieku. Jako jedną z najważniejszych książek tego kierunku badań można wymienić pracę $O$ indywidualności (Warszawa 1988) (Kulpińska, 2005, s. 329-334).

Każdy człowiek — według Szczepańskiego — jest niepowtarzalną jednostką, choć ukształtowaną społecznie. Postuluje on traktowanie indywidualności jako swoistego zadania człowieka, także jako jeden ze sposobów obrony przed złem. Zło ma swoje źródło przede wszystkim w życiu społecznym — także egoizm. Przeciwieństwem egoizmu jest poczucie obowiązku i odpowiedzialności jako społecznie zakorzenione zasady moralne (Szczepański, 1971; 1986a, s. 5; 1989a; 1993, s. 89-117). Tymi właśnie zagadnieniami, tj. diagnozą zła moralnego w społeczeństwie i problemami odrodzenia moralnego, będziemy zajmować się w dalszych 186 częściach niniejszych rozważań. 
Na pozornie proste pytanie „kim jest człowiek?” czy też „czym jest człowiek?” odpowiadały teologia i wiele innych nauk, jak filozofia, antropologia fizyczna i kulturowa, psychologia, socjologia, ekonomia i inne. Człowiek posiada jakieś cechy wyróżniające go wśród innych gatunków, czy to będzie specyficzny stosunek do Stwórcy (koncepcja teologiczna), czy stosunek do rozumu przenikającego świat (koncepcja filozoficzna), czy specyficzne zdolności, jak umysł, język, tworzenie symboli itp. Na ogół przyjmuje się, że każdy człowiek posiada jednakową w zasadzie strukturę psychofizyczną czy też może tylko psychiczną, wspólną całemu gatunkowi i tłumaczącą nie tylko miejsce człowieka w świecie, lecz także jego życie społeczne (Szczepański, 1970, s. 106-111). Przez naturę ludzką Szczepański rozumie ,zespół trwałych zdolności i sił motorycznych działających w organizmie ludzkim i zmuszających go do zaspokajania nie tylko potrzeb biologicznych, ale także do aktywnego przystosowania do środowiska społecznego i kulturalnego, zdolności do tworzenia wartości społecznych i kulturalnych" (Szczepański, 1970, s. 113).

W swoich rozważaniach nad sprawami ludzkimi Szczepański odwołuje się do idei człowieczeństwa i stwierdza, że wyobrażenia ludzi o człowieczeństwie są bardzo zróżnicowane. Dla jednych człowieczeństwo mierzy się umiejętnościami realizowania idei - moralnych, intelektualnych, estetycznych czy społecznych poprzez określone dzieła. Dla innych miarą człowieczeństwa nie jest dzieło, ale wierność ideom. Jednak są i tacy, dla których miarę człowieczeństwa stanowi sukces w działaniu, w polityce, na wojnie itp. Idea człowieczeństwa jest potrzebna jako miara i wzór, jako drogowskaz, który stanowi zbiór cech idealnych, konstrukt złożony z cech wyidealizowanych, będących odbiciem doskonałości Stwórcy.

Idea człowieczeństwa działa powoli, ale mobilizuje coraz potężniejsze siły, stwarza coraz silniejszy nacisk i coraz więcej ludzi musi się z nią liczyć. W życiu indywidualnym i społecznym jesteśmy jednak dalecy od tej doskonałości. Człowieczeństwa trzeba szukać nie tyle w świecie idei, ile w świecie ludzkim, tj. $\mathrm{w}$ świecie zewnętrznym lub wewnętrznym, lub w świecie powstającym między światami wewnętrznymi człowieka. We własnej pracy lub w korzystaniu z pracy innych tworzy się codziennie ludzkie człowieczeństwo, stąd wywodzą się jego cechy (Szczepański, 1984a, s. 75—88). W odczuciu przeciętnych ludzi to dobro lub chęć czynienia dobra powoduje, iż mówimy o kimś, że jest on ludzki. Bez względu na poziom zaawansowania intelektualnego każdy człowiek może czynić dobro.

„Dobro natomiast jest jedno i niepodzielne. Nie ma czynów więcej lub mniej dobrych — każdy czyn dobry jest taki sam. Nie ma zachowań mniej lub więcej dobrych. Kto chce i czyni dobro, jest człowiekiem. Wszystkie inne cechy występujące w umyśle i zachowaniu dowolnego egzemplarza homo sapiens, jak jego rozumność, zdolność do tworzenia sztuki, dążenie do sprawiedliwości, wolności, prawdy itp., są cechami wtórnymi. Kto nie chce czynić dobra, ten nie jest człowiekiem!" (Szczepański, 1984a, s. 81). Rozważania Szczepańskiego nad człowieczeństwem są nieco zawiłe, ale ogólnie rzecz ujmując, sytuują się nie tyle w ideach człowieczeństwa, co w realiach życia człowieka. Bliskie są one temu, co nazywamy godnością osobowościową i osobistą. Znamienne dla tych refleksji jest 
rozważanie człowieczeństwa w kontekście społecznym, a zwłaszcza w kontekście spraw życia codziennego, życia przeciętnych ludzi.

W teorii człowieka Szczepański przyjmuje dwa sposoby jego istnienia. Po pierwsze, jako istoty społecznej, będącej tworem uspołecznienia i wychowania w społeczeństwie. Od społeczeństwa człowiek przejmuje wiedzę, wartości, obyczaje, umiejętności praktyczne itp. Odpowiednio w swoich zachowaniach i działaniach odzwierciedla całość stosunków społecznych, w których wyrastał. Pod drugie, człowiek istnieje także jako niepowtarzalna indywidualność, wykazująca cechy właściwe tylko jej i wyróżniająca ją spośród wszystkich pozostałych członków gatunku (Szczepański, 1987d, s. 3; 1988). Taka koncepcja człowieka leży u podstaw rozważań nad moralnością jednostek, grup społecznych i całego społeczeństwa.

W diagnozie moralnej społeczeństwa polskiego Szczepański podejmuje m.in. zagadnienia moralności życia publicznego, w tym i moralności pracy. Odróżnia wyraźnie etykę i moralność. Etyka to nauka normatywna ustalająca, co jest dobrem, a co złem, oraz jakie powinny być dyrektywy kierujące postępowaniem i celowymi działaniami człowieka. Moralność odnosi się do zachowań ludzkich, które odpowiadają uznanym kryteriom dobra i doskonałości. Ważnym elementem moralności jest sprawiedliwość, wiążąca się z moralnym poczuciem słuszności. Związek sprawiedliwości z moralnością to czynnik powodujący zdecydowaną reakcję na niesprawiedliwość. Człowiek czyniący niesprawiedliwość jest naganny moralnie. Potępienie niemoralności jest sprawiedliwe, podobnie jak działania przeciwko niemoralności. Szczepański odróżnia „dobro” i „zło” jako kategorie nauki o moralności, gdzie mogą występować jako wartości istnienia oraz wartości etyki normatywnej ustalającej kryteria postępowania i działania jednostek i grup społecznych (Szczepański, 1995b, s. 253).

Moralność będąca dążeniem do dobra, do doskonałości w czynieniu dobra, może być traktowana jako wartość sama w sobie i pewien ideał (etyka) oraz instrumentalnie jako funkcjonująca w rzeczywistości w różnych dziedzinach życia społecznego (np. moralność pracy, moralność życia zbiorowego, moralność gospodarowania i stosunków gospodarczych, moralność życia publicznego). O moralności życia publicznego mówimy wtedy, gdy analizujemy zachowania i działania ludzi dotyczące spraw zbiorowych, jak produkcja dóbr i wykonywanie usług dla innych, załatwianie spraw w urzędach, wykonywanie władzy, stosunek obywateli do władzy i przedstawicieli władzy do obywateli, a także pod kątem przestrzegania zasad etyki w tych działaniach. Moralność życia publicznego składa się z wielu dziedzin, zaczynając od moralności pracy i wykonywania zawodu, do moralności współżycia na wszystkich płaszczyznach wzajemnych oddziaływań i stosunków społecznych; od moralności osobistej przejawiającej się w życiu rodzinnym i w poszanowaniu prawa, do moralności działań politycznych (Szczepański, 1980, s. $8-9)$.

Szczepański analizuje m.in. zagadnienia moralności w dziedzinie życia gospodarczego, w stosunkach produkcji, wymiany i konsumpcji oraz w zachowaniach gospodarczych. Moralność staje się czynnikiem wzrostu gospodarczego w tych 188 sytuacjach, w których systemy gospodarcze są uporządkowane prawem, kiedy 
miejsce wyzysku zajmuje współpraca, a miejsce zależności — współzależność. W systemie opartym na prawie każde jego naruszenie wprowadza do systemu dezorganizację i nieład. Kiedy pracownik rzetelnie wykonuje swoje czynności, cały system może funkcjonować rzetelnie, a moralność staje się czynnikiem optymalnego realizowania interesów gospodarczych. Naruszanie zasady sumienności, zła praca, łapownictwo, nieprzestrzeganie dyrektyw technologicznych i organizacyjnych musi prowadzić do dezorganizacji systemu. Te gospodarki i te jednostki gospodarujące, które nie respektują tych prostych prawd i naruszają zasady moralności gospodarowania, działają także przeciw swoim interesom. Gospodarka polska, pomimo wielu reform, nie może wyjść ze „stanu niemożności” (Szczepański, 1980, s. $10-11)$.

W wielu swoich pracach Szczepański podejmuje także zagadnienie pracy związanej z rozwojem gospodarczym. Przestrzeganie norm moralnych, podobnie jak wszelkie inne zachowania człowieka, jest uwarunkowane określonymi czynnikami życia zbiorowego. Dotyczy to także środowiska pracy zawodowej. „By być pracowitym, praca musi zaspokajać poczucie sensu pracującego, musi być pracą sensowną, prowadzącą do znanych i oczekiwanych wyników. Człowiek pracowity musi widzieć kumulowanie się wyników jego pracowitości — pracowici byli budowlani widzący, jak szybko rosną budowane przez nich domy i dzielnice. Trudno wymagać pracowitości, gdy praca jest źle zorganizowana i wyposażona. Lecz prawdą jest także, że bardzo często brak tych warunków, sprzyjających pracowitości, jest wynikiem właśnie lenistwa, braku umiejętności organizacyjnych, apatii i obojętności. Wtedy wytwarza się usprawiedliwienie własnego nieróbstwa zamiast tworzenia warunków do pracowitości” (Szczepański, 1987c, s. 167). Podobnie jest z przestrzeganiem innych norm moralnych i zaleceń etyki. Zawsze muszą być uwzględnione dwa kompleksy czynników: postawy i cechy jednostek oraz warunki zewnętrzne wyznaczające działania.

Jest wiele powodów, dla których ludzie podejmują pracę (wielość funkcji pracy). Po pierwsze, bez pracy ludzie nie mogliby żyć i zaspokajać swoich potrzeb, stąd większość podejmuje pracę z konieczności życiowej; po drugie, praca umożliwia utrzymanie pozycji w społeczeństwie; po trzecie, pozwala uzyskać poczucie sensu własnego życia, wypełnionego celową działalnością; po czwarte, praca daje poczucie zadowolenia z dobrze wykonanych czynności i poczucie dumy z własnej sprawności; po piąte, zapewnia prestiż w ocenie innych ludzi i uznanie dla zalet okazywanych w wykonywaniu pracy; po szóste, poprzez pracę ludzie osiągają potwierdzenie własnej wartości (Szczepański, 1986b, s. 6-7). Za ważne uznaje Szczepański: „każdy pracownik powinien być w stanie wyliczyć sobie kiedy i do czego dojdzie, w zależności od intensywności i wydajności swojej pracy. Młody pracownik podejmujący pracę powinien móc wyliczyć sobie, kiedy dojdzie do swoich celów życiowych w zależności od jakości swojej pracy na danym stanowisku pracy. Na tym polega subiektywny sens pracy, który może stać się czynnikiem motorycznym gospodarki” (Szczepański, 1987b, s. 9).

Praca nadaje — choć w różny sposób - sens ludzkiemu życiu. Praca ma służyć człowiekowi, nie odwrotnie — ma sprzyjać jego rozwojowi, samorealizacji, 
zaspokojeniu rzeczywistych potrzeb, a nie człowiek ma służyć pracy. Atrakcyjna praca nie sprowadza się do satysfakcji materialnej i do materialnego dobrobytu, ale stwarza przede wszystkim warunki do podmiotowego rozwoju, w której to, co indywidualne, wiąże się z tym, co społeczne. Pozaekonomiczne czynniki pracy oznaczają, że staje się ona bardziej sposobem na życie niż zarabianiem na nie. Takie pojmowanie pracy, przywracające jej należną godność, jest dzisiaj szczególnie ważne, tworzy swoistą etykę pracy, będącą do pewnego stopnia „siłą produkcyjną" (Szczepański, 1987c, s. 164).

Zagadnienia moralności życia publicznego są zawsze aktualne, zwłaszcza w okresach trudności czy kryzysu gospodarczego stają się przedmiotem dyskusji. W korupcji instytucji i w upadku moralności obywateli dostrzega się poważne zagrożenia dla dalszego rozwoju społeczeństwa. Wskazuje się na alkoholizm pociągający za sobą niski poziom jakości pracy i wydajności, a także na łapownictwo dezorganizujące sprawne funkcjonowanie instytucji państwa, na zanikanie poczucia obowiązku, przywłaszczanie sobie mienia społecznego. Wszystkie te zjawiska - występujące w określonym natężeniu - powodują osłabienie siły państwa i zagrożenie przyszłego rozwoju narodu. Do tych i wielu innych zagrożeń moralności życia publicznego Szczepański nawiązuje w wielu swoich raportach, opracowaniach specjalistycznych, raportach na zlecenie określonych ośrodków władzy, w diagnozach i prognozach, w propozycjach zmian społecznych, politycznych i gospodarczych (Szczepański, 1980, s. 13-14).

W podejmowanej przez Szczepańskiego problematyce dobra i zła pojawia się jeszcze dość często, zwłaszcza w latach 80. i 90. XX wieku, zagadnienie cierpienia. Istnieją różne rodzaje cierpienia. Jedne są skutkami intencjonalnych działań człowieka, motywowanych głupotą czy nienawiścią do innych ludzi, czy uleganiem złudzeniom. Istnieją też rodzaje cierpienia niezawinionego przez ludzi, zmuszonych do uczestniczenia w wojnach, wyzyskiwanych, prześladowanych za wiarę czy przynależność do grup politycznych i etnicznych, morderstwa. Szczególnie odrażającą postacią cierpienia niezawinionego jest torturowanie dzieci. Filozofowie, ideologowie, rewolucjoniści, reformatorzy, a także teologowie, politycy i różnego rodzaju utopiści tworzą wizje świata bez cierpienia. Nie można sobie jednak wyobrazić świata bez niego, gdyż wypadki losowe, choroby i konflikty nieubłagalnie niszczą życie ludzkie (Szczepański, 1995b, s. 101; Baniak, 2015, s. 206-209).

Cierpienie jest wpisane w doświadczenie człowieka i będzie istnieć zawsze. Cierpi człowiek jako osoba moralna i podmiot swoich doznań, przeżyć i doświadczeń. Na strukturę i sposób przeżywania cierpienia duży wpływ mają kultura, życie społeczne, postawa innych ludzi wobec cierpienia, poziom tolerancji na cierpienie i sposoby radzenia sobie z cierpieniem. „Człowiek nie chce się pogodzić z cierpieniem, którego sensem i celem jest przemijanie i śmierć. Szuka więc sensu życia w twórczości, w działaniu na rzecz innych ludzi, grup i społeczeństw, w religii głoszącej, że sensem życia jest istnienie pośmiertne, w filozofii analizującej drogi i metody poznawania świata, by tymi drogami dojść do poznania możliwości rozprawienia się z przemijaniem" (Szczepański, 1999a, s. 73). 
Wielu ludzi cierpiących, doświadczających zachwiania wewnętrznej równowagi, pesymizmu i smutku, odnajduje w religii nowy sens życia. Bez wątpienia choroba i cierpienia są granicą i próbą dla człowieka, są jednak także szansą rozwoju moralnego. Religia pomaga człowiekowi radzić sobie z sytuacjami stwarzanymi przez cierpienie, doszukiwać się w nich sensu i jakiegoś celu. Człowiek próbuje także poradzić sobie z cierpieniem, nawet w sytuacjach granicznych, gdy szuka pozytywnych skutków cierpienia w rozwoju własnej osobowości czy też w rozwoju grup społecznych (Szczepański, 1988, s. 133). Cierpienie może być zepchnięte w zapomnienie lub poddane interpretacji w perspektywie poszukiwania jego sensu, może być uznane za bezsensowne albo za mające jakiś sens, który trzeba tylko odnaleźć (Mariański, 2018a, s. 79-85).

Na pytanie, kto odpowiada za poziom moralności życia publicznego i w czym przejawia się troska o ojczyznę, Szczepański odpowiada bardzo konkretnie. Troska o ojczyznę zaczyna się od dbałości o własny wygląd, od troski o wygląd mieszkania, domu, ulicy, osiedla, wsi czy miasta. Ojczyzna to zakład pracy i wytwór pracy. Jeżeli z mojego zakładu wychodzą produkty źle wykonane, jest to ujmą dla honoru mojej ojczyzny. Naród pijący nadmiernie, uciekający w narkotyki, o wysokim stopniu przestępczości, nie tylko osłabia się gospodarczo, lecz także wytwarza niebezpieczny dla jego przyszłości ujemny obraz w skali międzynarodowej (Szczepański, 1980, s. 14-15).

Na pytanie, kto jest odpowiedzialny za poziom moralności życia publicznego: władza czy obywatele, odpowiada krótko: „Jako człowiek wychowany w protestanckiej kulturze odpowiedzialności za siebie i za swoje czyny uważałbym za obelgę, gdyby mi wmawiano, że jakiś rząd może ze mnie zrobić pijaka czy człowieka nie wykonującego swoich obowiązków. Za siebie i za swoje postępowanie odpowiadam sam i uważam, że za poziom moralności publicznej odpowiadają obywatele. Władza odpowiada za moralność życia publicznego, politycznego i za moralność postępowania przedstawicieli władzy. Trzeba starannie odróżniać sytuacje, kiedy funkcjonowanie władzy stwarza warunki sprzyjające upadkowi moralności obywatelskiej od tych sytuacji, kiedy obywatele chętnie korzystają z warunków wytwarzanych przez władzę, aby usprawiedliwić swoją niską moralność życia publicznego" (Szczepański, 1980, s. 15).

Badania nad kondycją moralną społeczeństwa polskiego mają już długą tradycję. Były one prowadzone także przed 1989 rokiem. Szczepański zajmuje się w jednym ze swoich artykułów swoistą socjologią zła i opisuje różne przejawy zła moralnego w społeczeństwie polskim, ukazuje różne metody eliminacji zła oraz czynności wychowawcze w stosunku do dzieci, młodzieży i dorosłych, działania wskazujące, jak należy postępować w rozmaitych sytuacjach konfliktowych, jak kształtować motywację do pracy i działania represyjne w stosunku do przestępstw, a także jak tworzyć struktury społeczne i gospodarcze utrudniające lub ograniczające zachowania niepożądane, wreszcie jak tworzyć klimat, w którym ludzie sprzeciwiający się złu będą czuli się silni i przekonani o skuteczności swoich działań. Zło nie zostanie wykorzenione w pełni ze społeczeństwa, ale wszelkie aktywności na rzecz społeczeń- 
stwa moralnego są godne poparcia (Prof. Jan Szczepański, socjolog, 1986, s. $242-247)$.

Potrzebne są także badania empiryczne ukazujące rozmiary zła moralnego w społeczeństwie. Badani Polacy częściej zwracają uwagę na zjawisko zakłamania i dwulicowości w życiu publicznym, przywłaszczania sobie mienia państwowego i niesprawiedliwego odnoszenia się ludzi do siebie niż na zjawiska niedochowywania powierzonych tajemnic, niechęci do wzajemnej pomocy w trudnych sytuacjach życiowych i nielojalności małżeńskiej. Postępuje proces funkcjonalizacji stosunków międzyludzkich oraz tendencja do zamykania się w obrębie małych grup społecznych. W istniejącej sieci powiązań społecznych z trudem są realizowane potrzeby życzliwości i zaufania (Mariański, 1990, s. 152-240; 2018b, s. 58-59; Lindenberg 1991, s. 528 - 529). Negatywne oceny społeczeństwa nie sprzyjają zapewne kształtowaniu się nastawień prospołecznych, przekonanie zaś, że wielu ludzi postępuje niemoralnie, nie jest siłą aktywnie pobudzającą do przeciwdziałania negatywnemu stanowi rzeczy. Wyniki badań empirycznych z zakresu socjologii zła są wyzwaniem dla wielokierunkowej pracy wychowawczej w społeczeństwie.

\section{Kondycja moralna społeczeństwa wyzwaniem dla odrodzenia moralnego}

W kontekście kryzysów społecznych, kulturalnych, politycznych i gospodarczych co jakiś czas pojawiają się hasła odrodzenia moralnego, rewolucji moralnej, odnowy moralnej, reformy etycznej itp. W połowie lat 80 . ubiegłego wieku Szczepański pisał, że kampanie na rzecz odrodzenia moralnego mają na celu wyeliminowanie z życia publicznego różnego rodzaju patologii, tj. zjawisk odchylających się od norm moralnych, obyczajowych i prawnych, w przekonaniu, że życie codzienne stanie się wówczas łatwiejsze, bardziej przyjemne, zwiększy się dobrostan psychiczny i dobrobyt. Jeżeli wszyscy obywatele, a przynajmniej ich większość, będą pracowici, obowiązkowi, rzetelni, lojalni, solidarni, gdy będą przestrzegać nie tylko norm prawnych, ale i moralnych, wówczas odmieni się nasze życie, wyjdziemy z kryzysu, odbudujemy naszą gospodarkę, łatwiej spłacimy długi itp. Rozmaite instytucje domagają się stworzenia „mechanizmów” gwarantujących to, że normy moralne będą częścią składową wyposażenia kulturowego ludności kraju (Szczepański, 1987c, s. 164-165).

Według Szczepańskiego droga do zmian w moralności, droga do stworzenia społeczeństwa, w którym normy moralne są przestrzegane, musi iść dwoma torami. Po pierwsze, odpowiednie instytucje powinny tworzyć warunki powodujące, że przestrzeganie norm moralnych stanie się zachowaniem sensownym i sprzyjającym realizacji celów życiowych członków tego społeczeństwa. Po drugie, członkowie tego społeczeństwa nie powinni nawracać innych przez głoszenie kazań umo- 
ralniających, lecz rozpocząć pracę nad umoralnianiem własnego postępowania. W tworzeniu moralnego społeczeństwa trzeba zacząc od siebie (Szczepański, 1987c, s. 168). Jest to jedyna, niezwykle trudna droga do tworzenia takiego społeczeństwa. Hasło odrodzenia moralnego brzmi: „Zacznijmy od siebie. Przecież normy moralne, religijne są nam dobrze znane. Wiemy, co powinniśmy czynić. Gdy ktoś w jakiejś sytuacji mówi »nie wiem co czynić« — znaczy, że nie chce zrobić tego, co zrobić powinien. A dlaczego od czterdziestu lat w szkolnictwie zawodowym o etyce zawodowej mówi się prawie tyle co nic?" (Szczepański, 1987c, s. 168).

Podsumowując wyniki ze spotkania przewodniczącego Rady Państwa z przedstawicielami środowisk opiniotwórczych oraz działaczami społecznymi i państwowymi w dniu 7 kwietnia 1986 roku, Szczepański podejmuje próbę dokonania klasyfikacji różnych przejawów zła moralnego w społeczeństwie. Po pierwsze, przejawy zła związane są z procesami fizjologicznymi organizmu, mając cechy choroby, ale są wywoływane przyczynami społecznymi i mającymi ujemne skutki społeczne. Są to m.in. alkoholizm i uzależnienie od narkotyków. Ograniczenie tych negatywnych zjawisk wymaga leczenia, opieki społecznej, odpowiedniej polityki państwa i działań w mikroskali (rodzina, kolektywy pracy, kręgi koleżeńskie itp.). Jest to ogromny zakres działań. Po drugie, różne formy przestępczości, jak włamania, napady rabunkowe, kradzieże oraz inne przestępstwa popełniane przez „zawodowych” przestępców. Te przestępstwa są popełniane szczególnie wtedy, gdy są wspierane przez szersze grupy społeczne oraz swoisty klimat ułatwiający przestępczość.

Po trzecie, to przestępstwa popełniane w czasie „służby”, kradzieże popełniane przez SOK, różne postacie korupcji funkcjonariuszy instytucji gospodarczych i administracyjnych. Nadużycia władzy, wykorzystywanie możliwości służbowych dla osobistych korzyści, to zjawiska szczególnie rzucające się w oczy. Należy wskazać jeszcze zjawiska szczególnie groźne, ale trudne do ustalenia i wyeliminowania, jak niewykonywanie obowiązków, zwykłe niedbalstwo i lenistwo, unikanie podejmowania inicjatyw, unikanie odpowiedzialności, asekuranctwo itp. Po czwarte, to kategoria zła nazywana „bezinteresowną nienawiścią” czy też „bezinteresowną chęcią szkodzenia", ale i ogólna nieżyczliwość, zawiść, wykorzystywanie stanowisk służbowych dla intryg przekształcających stosunki pracy w koszmar udręczenia. Po piąte, zło wynikające z cech psychiki ludzkiej, ze słabości, głupoty, ignorancji, namiętności, ze źle pojętych celów życia, z nadmiernych ambicji itp. (Prof. Jan Szczepański, socjolog, 1986, s. 242-247).

Te i zapewne wiele innych przejawów zła moralnego wymaga przeciwdziałania. Jeżeli nawet wskazywane metody wychowania moralnego są do pewnego stopnia skuteczne, to nie ma jednego cudownego środka absolutnie skutecznego wobec wszystkich przejawów zła. Każda postać zła moralnego wymaga swoistych metod. Wszelkie wysiłki organizacyjne i wychowawcze przyczyniają się do eliminowania zła, ale nie doprowadzą do stworzenia jakiegoś w pełni moralnego społeczeństwa. Według Szczepańskiego wszelkie braki i błędy występujące w naszym społeczeństwie łatwiej można sprowadzić do wad organizacyjnych instytucji, do nadmiaru 
aktywności administracyjnej itp., niż do podstawowych (egoistycznych) cech człowieka (Szczepański, 1969, s. 21).

Problematyka dobra i zła społecznego i moralnego pojawia się w wielu pracach Szczepańskiego. Dobro i zło zaznaczają się w działaniach człowieka jako jednostki, a także - w instytucjach społecznych, w różnych ustrojach politycznych. Zwłaszcza problemy zła moralnego pojawiają się w rozmaitych analizach życia społecznego, zarówno w ustroju socjalistycznym, jak i kapitalistycznym oraz w społeczeństwie polskim po 1989 roku. Po obaleniu socjalizmu i wprowadzeniu gospodarki rynkowej i demokracji parlamentarnej społeczeństwo polskie przeżyło wiele afer gospodarczych, kradzieży i mordów, zostało dotknięte bezrobociem i nędzą pociągającą za sobą wzrost liczby samobójstw, poznało problem bezdomności, młodzież ogarnęła fala narkomanii (Szczepański, 1995b, s. 89).

„Wszystko to wyzwalało szok moralny, tym ostrzejszy, że po upadku socjalizmu nastąpiło odrodzenie religijne, intensyfikacja działalności kleru, że księża pojawili się we wszystkich dziedzinach życia publicznego i prawie wszystkie zorganizowane formy życia społecznego znalazły swoich opiekunów duchowych. Bezsilność Kościoła wobec tej fali zła i jego nowych postaci jest doświadczeniem równie ostrym jak bezsilność socjalizmu wobec tego zła. Sądzę, że nauki społeczne nie wykorzystały dostatecznie tej wielkiej okazji do badań naukowych nad problemem zła, pozostając raczej na poziomie uproszczonej wizji, formułującej swoje obserwacje w języku potocznym" (Szczepański, 1995b, s. 89).

Zło jest zasadniczym elementem świata, przede wszystkim świata ludzkiego, lub nawet szerzej - jako funkcjonalnie powiązanego z wszelkimi przejawami życia. Szczepański w różnych swoich pracach omawia rozmaite rodzaje zła. W sposób całościowy podjął zagadnienie zła w życiu jednostek i społeczeństwa w artykule Człowiek w strukturach zła, opublikowanym w kwartalniku Instytutu Jana Pawła II Katolickiego Uniwersytetu Lubelskiego pt. „Ethos”.

Zło istnieje jako względnie samodzielny czynnik egzystencji człowieka, wytwarza własne struktury i człowiek jest $\mathrm{w}$ te struktury uwikłany. Nie tkwi ono w samym człowieku pojmowanym jako indywidualność. Indywidualność to swoista postać istnienia, która nie zależy od cech gatunkowych, ani od cech społecznych ani zinternalizowanych wartości kultury, ale jest światem autonomicznym, zdolnym do samodzielnego tworzenia własnego świata wewnętrznego i do przekształcania świata zewnętrznego. Jako indywidualność człowiek może istnieć poza strukturami zła, poza społecznymi kontekstami czynienia zła, a zatem może istnieć w przestrzeni, w której nazwy dobro i zło tracą sens (Szczepański, 1992a, s. $66-68,76)$.

Tak pojmowany człowiek nie może jednak wyzwolić się ze związków ze społeczną osobowością, z uwikłania w sprawy społeczeństwa, nie może wyzwolić się ze związków z cechami gatunkowymi. Człowiek jest także istotą społeczną i jako taki uczestniczy w różnych formach życia zbiorowego, współpracuje z innymi lub ich zwalcza, zależnie od sytuacji i konstelacji warunków życia tych grup. We wzajemnym współżyciu ludzkim, w strukturach społecznych rodzi się zło,

194 kształtują się struktury zła. Każda forma współżycia społecznego „zawiera” także 
elementy rodzące niezawinione cierpienia. Członkowie społeczeństwa podlegają prawom współżycia i współdziałania, które zawsze mogą tworzyć pewne postacie zła (Szczepański, 1992a, s. 76).

Zło działań ludzkich wydaje się możliwe do eliminacji, gdyż wolna wola daje człowiekowi możliwość nieczynienia zła. Mimo wysiłków podejmowanych od tysiącleci zło utrzymuje się w postaci nędzy, głodu, prześladowan, terroru władzy, ucisku, niewolnictwa, ludobójstwa itp. Działania w imię dobra i walka o dobro nie przynoszą oczekiwanych rezultatów. Szczepański analizuje szczegółowo trzy próby eliminacji zła: reformy, rewolucje i walkę o dobro. Wszystkie one są nieskuteczne, gdyż każda walka o dobro rodzi zło. Każdy członek gatunku, każdy członek społeczeństwa i każda osoba uspołeczniona nosi w sobie korelaty zła istniejącego w zewnętrznych strukturach, stąd w walce o dobro wykorzystuje elementy zła, przekreślając możliwość pełnej realizacji celów. Szczepański podkreśla, że społeczne mechanizmy zadawania cierpienia są zawsze czymś pochodnym wobec mechanizmów jednostkowych. Dlatego też każde dążenie do zmniejszenia cierpienia w społeczeństwie trzeba zaczynać od dążenia do eliminacji własnych, osobistych, jednostkowych dążeń do zadawania cierpienia innym (Szczepański, 1987d, s. 3).

Życie zbiorowe opiera się przede wszystkim na tym, co ludzie powtarzają, naśladują, zapewniając w ten sposób zbiorowościom ciągłość i trwałość. Rozwój wynikający z innowacji, a także wprowadzanie nowych idei, wartości i to wszystko, co wynika z twórczości, jest dziełem indywidualności (indywidualność to nie indywiduum). Powszechnie sądzi się, że drogą do eliminacji zła i cierpienia jest uspołecznienie jednostek tak, by czuły się one w pełni członkami społeczeństwa. $\mathrm{W}$ ten sposób można będzie je skłonić do działania na rzecz dobra. Zapominamy wówczas, że złe strony natury człowieka pojawiają się wszędzie tam, gdzie dąży on do władzy, majątku czy zarobku, do stanowisk i prestiżu, czyli gdzie występuje oddziaływanie człowieka na człowieka.

„Wychowanie do życia w społeczeństwie, uspołecznienie, z konieczności musi także przygotowywać do walki, do konkurencji, do umiejętności osiągania celów i realizowania własnych interesów, które z konieczności łączą się z zadawaniem innym cierpień. Uspołecznienie młodych pokoleń, znane z historii, nie przyczyniało się do eliminacji zła w takim zakresie, jak tego starsze pokolenia oczekiwały. Sądzę więc, że trzeba większą uwagę zwracać na indywidualność, gdyż wkład twórczy człowieka w rozwój społeczeństwa jest zawsze wkładem wypromieniowanym z niepowtarzalnej indywidualności” (Szczepański, 1967d, s. 3).

Jest tylko jeden sposób istnienia człowieka, który może być niezależny od wszelkich struktur zła, mechanizm życiowy mogący skutecznie eliminować zło z jego życia — to indywidualność. Siły ludzkie, które można wykorzystać w eliminowaniu zła z życia jednostek i społeczeństwa, nie tkwią $\mathrm{w}$ zbiorowościach społecznych, ale „mieszczą się” w indywidualnościach ludzi. „Indywidualność jest tą sferą istnienia człowieka, w której nie występują żadne cechy społeczne ani gatunkowe, która składa się z cech i własności nie występujących u innych ludzi i która wytwarza własny świat wewnętrzny, nie mający żadnych korelatów świata 
zewnętrznego. W zakresie swojej indywidualności człowiek jest sam ze sobą, $\mathrm{w}$ jego świecie wewnętrznym nie ma innych ludzi i dlatego nie ma w nim także zła. Zło bowiem rodzi się w świecie międzyludzkim ze wzajemnego oddziaływania między społecznymi strukturami i ich korelatami w społecznej naturze człowieka, czy w naturze gatunkowej, biologicznej” (Szczepański, 1992a, s. 75).

Indywidualność przejawia się przede wszystkim w twórczości artystycznej, ale można ją dostrzec także w każdej twórczości „małej” każdego człowieka, który w zakresie podejmowanej przez siebie działalności coś zmienia, ulepsza, organizuje, tworzy. Rola indywidualności w życiu jednostek, w tworzeniu nowych elementów życia zbiorowego, w rozwoju społeczeństw i kultur jest ogromna. „Odwołanie się do indywidualności oznacza odwołanie się do sił twórczych człowieka. Gdy społeczeństwo ulega skłonnościom patologicznym, gdy nie może opanować fali przestępczości, jest rzeczą jednostek, by we własnej indywidualności znajdowały siły moralne i zdolności intelektualne, wolę i upór pozwalające im osiągnąć cele życiowe i działać zgodnie z zasadami moralności” (Szczepański, 1984b, s. 4).

Indywidualność jednostki jest najważniejszą instancją w eliminowaniu zła. Istnieją także różnorakie mechanizmy i sposoby, przez które społeczeństwo żąda i wymusza respektowanie podstawowych zasad i norm. Natomiast wychowanie w sensie moralizowania ma ograniczone skutki. Wychowywać jednak trzeba, a „podstawowym warunkiem skuteczności wychowania moralnego jest stosowanie nauczanych zasad moralnych w codziennej praktyce przez wszystkich członków społeczeństwa. Jeżeli warunek ten nie jest spełniony, wychowywana młodzież szybko spostrzega, że werbalne powtarzanie zasad jest koniecznością, ale stosować się do nich trzeba tylko w takim zakresie, jak to czynią wszyscy" (Szczepański, 1984b, s. 3).

Szczepański szczególnie dobitnie podkreśla rolę pracy jako środka i ważną moralnie metodę osiągania celów. „Można jeszcze wybrać oszustwo, rozbój, kradzież, cwaniactwo, hazard, szukanie przywilejów, czepianie się "pańskiej klamki« i co tam jeszcze różnego rodzaju ludzki poślad może wymyślić. Przestrzeganie praw indywidualności i szacunek dla własnej indywidualności nakazuje mi trzymać się zasad godności, nie warto oszukiwać samego siebie" (Szczepański, 1984b, s. 4). Jeżeli nawet założone idee, plany i aspiracje nie dają się w pełni zrealizować, to pozostaje dążenie do nich, szukanie nowych dróg ich urzeczywistnienia, próby stosowania ich w małym zakresie codziennych poczynań. Zmierzamy wówczas do osiągniecia „ograniczonego dobra”. Następnym pokoleniom powinniśmy przekazać szacunek dla indywidualności jako podstawę ludzkiej twórczości we wszystkich zakresach życia (Szczepański, 1984b, s. 4).

Pozostaje jednak otwarte pytanie, jak konkretnie opisać i wyjaśnić funkcjonowanie indywidualności w życiu poszczególnych osób oraz w życiu społeczeństw, a zwłaszcza uwolnienie człowieka od — jak się wydaje — immanentnego zła i jego skutków. Zaznacza się w tej koncepcji swoista przepaść między orientacją na autonomię indywidualności, $\mathrm{z}$ niebezpieczeństwem zamykania się $\mathrm{w}$ swoim świecie wewnętrznym, a światem zewnętrznym przenikniętym różnymi przejawami zła.

196 W sposób niezwykle wymowny opisał swoje wątpliwości w tych sprawach prof. 
Zbigniew Sufin, bliski współpracownik prof. Jana Szczepańskiego, po przeczytaniu książki $O$ indywidualności.

„Jak przeczytałem ją po raz pierwszy, byłem zdezorientowany. Nie potrafiłem zrozumieć relacji między światem wewnętrznym a światem zewnętrznym w ogólnej koncepcji indywidualności mojego Mistrza. Profesor Jan uważał świat wewnętrzny człowieka za podstawę jego autonomii wobec świata zewnętrznego. Świat wewnętrzny to ostoja autonomii osoby — pisał - nie tylko wobec nacisków społeczeństwa i kultury, ale także wobec popędów biologicznych i psychologicznych. Istotę indywidualności Profesor łączył jedynie ze światem wewnętrznym człowieka przypisując jej tak różne funkcje, jak autonomia działania, wartość osoby, tożsamość osoby, twórczość osoby, rozprawy z samotnością i osamotnieniem, rozprawy z czasem i z losem, a także radzenie sobie ze śmiercią. Tak rozumiana indywidualność to podstawa wartości człowieka i czynienia przez niego dobra. Zewnętrzny świat społeczny, w koncepcji indywidualności Jana Szczepańskiego, to świat walki o byt, konkurencji, zawiści, nienawiści, dążenia do bogactwa i wiedzy. Natomiast dobro, miłość, solidarność są »importem« indywidualności - pisał. Profesor Jan wyrażał wątpliwość, czy indywidualność jako ostoja dobra może oddziaływać skutecznie na świat zewnętrzny pełen przejawów zła. Mimo to uważał, że indywidualność »uświadomiona« i »wyrażana« jest szansą w przezwyciężaniu zła, że »można przeciwstawiać się złu tylko na podstawie indywidualnych sił wewnętrznych«" (Sufin, 2005, s. 254).

Wskazania Szczepańskiego: od diagnoz do działań, jakkolwiek odnosiły się do społeczeństwa zwanego socjalistycznym (przed 1989 rokiem), wydaje się, że zawierają w swojej znacznej części aktualność. Także i dzisiaj stawiamy pytania o to, jakie jest społeczeństwo polskie (diagnoza), ale też jak skutecznie doskonalić to społeczeństwo (propozycje dobrego społeczeństwa). W diagnozach społeczeństwa polskiego i propozycjach reform Szczepańskiego pojawiał się problem zła i odrodzenia moralnego. Zło jest rzeczywistością wielowymiarową. Może być rozważane jako koncepcja metafizyczna, koncepcja religijna, jako czyn jednostkowy lub zbiorowy, przejaw działań politycznych i społecznych (Szczepański, 1999b, s. 91). W pewnym sensie można uznać Szczepańskiego za prekursora subdyscypliny socjologicznej zwanej socjologią zła. Zadanie socjologii zła stanowi zdiagnozowanie i zrozumienie tego, co jest złem (w terminologii teologicznej — grzechem) we wszelkich jego przejawach, przy zastosowaniu socjologicznych metod i narzędzi badawczych, dla jego pomniejszenia w życiu jednostek i społeczeństwa (Wargacki, 2015, s. $758-761)$.

Szczepański jako socjolog ma rację, należy rozwijać zarówno etykę instytucji, jak i etykę indywidualnych postaw. Nasuwa się jednak pytanie: czy poza sformułowaniem ogólnych wskazań socjologia może zrobić coś więcej? Czy może uprawomocnić konkretne wskazania zmierzające do urzeczywistnienia społeczeństwa moralnego? Czy rzeczywiście zmiana $\mathrm{w}$ indywidualnych postawach wywoła samoczynnie pożądane skutki $\mathrm{w}$ innych dziedzinach życia? W jakim zakresie socjolog może współdziałać w tworzeniu i urzeczywistnianiu wizji dobrego moralnie społeczeństwa i włączyć się w urządzanie świata społecznego w imię 
sprawiedliwości i ludzkiej godności? Tego typu pytania należy traktować jako dyskusyjne i do pewnego stopnia „otwarte”.

Wielu socjologów sądziło i nadal sądzi - stwierdza Szczepański w referacie wygłoszonym w Lublinie na IX Ogólnopolskim Zjeździe Socjologicznym w dniu 27 czerwca 1994 roku — że socjologowie są przede wszystkim uczonymi tworzącymi zobiektywizowaną i zweryfikowaną wiedzę naukową. Inni uważali, że ta wiedza naukowa uzasadnia ich występowanie jako reformatorów albo jako aktywnych polityków, doradców politycznych czy socjalnych. Inni ograniczali swoją działalność publiczną do publicystyki.

„W moim długim i urozmaiconym życiu próbowałem występować w prawie wszystkich wymienionych tu rolach. Uważałem bowiem, że socjolog wiedząc, powinien swoją wiedzę użytkować z korzyścią dla bliźnich. Uprawiałem mozolnie socjologię empiryczną, doradzałem politykom, pisałem analityczne raporty, projektowałem reformy, występowałem w parlamencie, przewodniczyłem komitetom, ostrzegałem itp. Nie żałuję tego bogatego życia, ale doszedłem do wniosku, że socjolog powinien być przede wszystkim uczonym, badaczem tworzącym naukę, gdyż w każdej innej funkcji łatwo go zastąpią legiony innych praktyków, a w tworzeniu wiedzy naukowej nie zastąpi go nikt" (Szczepański, 1995a, s. 22).

Profesor Szczepański był przede wszystkim uczonym, badaczem tworzącym naukę. Jego socjologia była bardzo zróżnicowana w tym sensie, że sytuowała się w kilku co najmniej subdyscyplinach socjologicznych. W latach 80. i 90. XX wieku coraz częściej pojawiały się tematy związane z problemami ludzkimi, jak indywidualność, sens życia i sens cierpienia, dobro i zło moralne, religia i moralność, wychowanie moralne, odrodzenie (rozwój) moralne. Te wszystkie tematy - w warstwie diagnostycznej i działaniowej — układają się w miarę zwartą koncepcję dobrego życia, które czeka na całościowe opracowanie (Rosińska, 2007).

Szczepański twierdzi, że „wartość życia polega na osiąganiu optimum w każdym wymiarze, w którym żyjemy, optimum dopuszczalnego przez obiektywne wyznaczniki i warunki przebiegu życia jednostki oraz optimum dopuszczalne przez jej subiektywne wyznaczniki i warunki. Wartościowe jest życie człowieka, który jest $\mathrm{w}$ takim stanie zdrowia i sprawności, jaki jest dla niego możliwy, którego władze psychiczne, zdolności i wszystkie mechanizmy psychiki działają harmonijnie i w granicach swoich możliwości, który do życia społeczeństwa wnosi dzieło optymalnie doskonałe, na jakie go stać, który wnosi do kultury i jej wartości wszystko, co jest dla niego możliwe, i który z dziedzictwa kulturowego swojego społeczeństwa wziął wszystko, co mogłoby wzbogacić jego doznania, przeżycia, kontemplacje, który jest ekonomicznie samodzielny i osiąga swoje cele, który z rodziną, wszystkimi grupami, w jakich uczestniczy, żyje w stosunkach optymalnych w danych warunkach. [...]. Subiektywne odczucie wartości życia jest bowiem zawsze ściśle powiązane z możliwością realizacji celów, osiągnięcie których uważa za »spełnienie siebie« i o nich mówi: "po to żyłem, by te cele osiągnąć «" (Szczepański, 1986c, s. 188-189) 


\section{Refleksje ogólne nad rewitalizacją moralności w społeczeństwie}

Socjologia ustala, co rzeczywiście w społeczeństwie jest wartością moralną, nie zaś to, co nią być powinno. Wyjaśnia zjawiska moralne, poszukując ich przyczyn i wskazując na funkcje, jakie te zjawiska pełnią. Wypowiada sądy o rzeczywistości, ale nie formułuje praw uniwersalnych, ani sądów o wartościach. Jej rekomendacje dotyczące „dobrego” czy „moralnego” społeczeństwa są w istocie dość ograniczone. Nie może jednak ona całkowicie abstrahować od ważnych społecznie i etycznie pytań: jak kształtować życie wspólnotowe i wspólne podstawy życia społecznego w warunkach zanikania uniwersalnych wartości łączących ludzi nawzajem i w warunkach zakwestionowania autorytetów moralnych? Czy może funkcjonować pluralistyczne społeczeństwo bez bazy wspólnych wartości, rzeczywiście wiążących wszystkich? W społeczeństwie, w którym nic nie jest ogólnie wiążące, istnieje niebezpieczeństwo, że wartości i normy wypracowane z trudem w przeszłości pozostaną porzucone raz na zawsze. Nierozwiązany będzie problem ważny dla wychowania moralnego — jak powinniśmy żyć w społeczeństwie bez autorytetów i norm ${ }^{1}$.

W dziedzinie wartości i norm ostatnie słowo nie należy do socjologów. Przemiana wartości i norm moralnych nie oznacza ipso facto ich upadku, dlatego też każda zmiana wymaga etycznej oceny, chociaż ta nie należy bezpośrednio do socjologów. Z pedagogicznego punktu widzenia możemy stawiać wielorakie, etycznie ważne pytania. Moralność odnosimy wówczas do wartości powinnościowych. Wszechobecny w naszym społeczeństwie i kulturze relatywizm moralny, który niczego nie uznaje za ostateczne i dla którego podstawowym kryterium jest pragmatyczne „ja”, stanowi groźną przeszkodę w wychowaniu do wartości uniwersalnych. Jeżeli nawet z socjologicznego punktu widzenia można twierdzić, że wartości są konstruktem społecznym, to nie jest bynajmniej czymś irracjonalnym oczekiwanie, że społeczeństwa nie będą wyprane $\mathrm{z}$ wartości i będą w nich zasady wymagające lojalności i poszanowania godności osoby ludzkiej (Mariański, 2008, s. 33-34).

Pytanie, co jest zmienne a co trwałe w normach i stojących za nimi wartościach moralnych, jest niezwykle ważne także dla socjologa, chociaż nie rozstrzyga on problemu, czy istnieją obiektywne, ogólnie obowiązujące wartości i normy moralne, niezależne od świadomości zbiorowej. Może on jednak przyjmować tezę, że jednostki i społeczeństwa bez wartości i norm są po prostu fikcją, a modernizacja społeczna nie musi wiązać się koniecznie z negacją wartości moralnych. Socjolog empiryk stoi raczej po stronie umiarkowanych relatywistów, gdyż ustawicznie opisuje zmieniającą się rzeczywistość moralną, ale z tej wielości nie wyciąga

\footnotetext{
1 „Rzecz w tym, że nie ma gotowych, jednolitych i spójnych rozwiązań — zwłaszcza w zakresie wychowania moralnego - światopoglądowych i w zakresie edukacji obywatelskiej. Wraz z wolnością polityczną i otwartością informacyjną i komunikacyjną szerokim otworem stały się dostępne różnorodne wręcz migotliwe w swej wielości i zmienności oferty kulturowe" (Kwieciński, 2004, s. 154).
} 
wniosku o nieistnieniu wartości uniwersalnych, nie przeczy istnieniu idei prawdy. Pozostaje kwestią otwartą, czy i w jakim stopniu socjologia może stawiać sobie pytania normatywne, stając się czymś więcej niż tylko wiedzą podającą spóźnione informacje o faktach społecznych. Dokonując tego historycznego zwrotu, mogłaby jednak unieważnić teoretyczny rozdział pomiędzy poznaniem faktów i powinności.

W warunkach narastających kulturowych orientacji o charakterze indywidualistycznym i utylitarystycznym, opierających się na sceptycyzmie i relatywizmie etycznym, ważna staje się refleksja nad tym, co określa się skrótowo jako dobro wspólne społeczeństwa na miarę godności człowieka, a także poszukiwanie nowych wartości i norm moralnych kształtujących się w warunkach szybkich zmian społecznych. Wydaje się, że współpraca socjologów z tymi, którzy usiłują budować moralnie dobre społeczeństwo (oparte na wartościach), może być bardziej intensywna niż dotychczas, nawet jeżeli dotyczyłaby ona bardziej płaszczyzny tego, jak jest, niż tego, jak być powinno, lub co zrobić, aby było inaczej. Najogólniej chodzi o uznanie pewnych trwałych wartości moralnych, czy innych elementów niepodlegających relatywizacji.

Jedno wydaje się pewne, że dalszy zanik autorytetów moralnych, uprawomocnienie się wszystkich opinii bez względu na ich treść, podważanie znaczenia wspólnych reguł społecznych - grozi nam w konsekwencji nie tylko permisywizmem, ale i uogólnionym relatywizmem. Coś w życiu społecznym musi obowiązywać bezwzględnie, inaczej będzie się upowszechniać chaos i anomia. W bardzo labilnym społeczeństwie potrzebne są stabilne wartości, a społeczeństwa mogą istnieć i przetrwać dzięki wartościom i normom społeczno-moralnym. Szanując godność człowieka i wypływającą z niej wolność, trzeba go wspomagać w samodzielnym i odpowiedzialnym decydowaniu o jego życiu. Nie wystarczy tylko zwiększenie wiedzy o normach moralnych ani zewnętrzne dyscyplinowanie moralne, ważniejsze jest wzmacnianie kompetencji etycznych jednostek (moralna siła naszego „ja”) i tworzenie warunków ułatwiających postępowanie moralne, w bardziej przyzwoitym społeczeństwie. Postawy i zachowania każdego człowieka składają się na treść moralną społeczeństwa. Odbudowa społeczeństwa jako całości musi akcentować wymiar społeczno-moralny. To jedyna droga wyjścia $z$ wielorakich kryzysów. Tego rodzaju postulaty są zbieżne z tymi, które formułował 30 —40 lat temu Szczepański.

Mogą sobie socjologowie opisywać różne przejawy aksjonormatywnego relatywizmu w społeczeństwie, mogą zachwycać się demontażem drogowskazów etycznych w życiu codziennym w ponowoczesnych społeczeństwach, mogą nawet lekceważyć wywody etyków na temat powszechności czy obiektywności wartości i norm moralnych, ale muszą zdawać sobie sprawę, że ich przekonania o tym, iż ,systemy aksjonormatywne zawsze są produktem okoliczności kulturowych i historycznych, co oznacza, że bywają czymś stałym jedynie przez jakiś czas" (Szlendak, 2004, s. 21), to tylko część prawdy o kondycji moralnej człowieka. Pluralizm czy relatywność wartości moralnych w społeczeństwie jest faktem, ale nie normą czy ideałem. Nie sposób wychowywać do relatywizmu 200 moralnego według reguły: dzisiaj przekazuję ci takie oto wartości i normy, ale są 
one tymczasowe, jutro mogą być inne lub nawet z pewnością będą inne. Potrzebne są stałe drogowskazy aksjologiczne i normatywne, przede wszystkim wartości o charakterze uniwersalnym.

Wychowanie moralne - rozważane z socjologicznego punktu widzenia doprowadza do takiego punktu rozwoju osobowościowego, w którym jednostka rozstrzyga o wartości moralnej swoich działań, o tym, co słuszne lub niesłuszne, uczciwe lub nieuczciwe, opierając się na powszechnie uznawanych w danej kulturze zasadach, celach i ideałach moralnych. Taki rozwój moralny jest procesem długotrwałym i wielorako uwarunkowanym, przeciągającym się głęboko w okres życia dojrzałego. Pełna autonomia moralna, będąca znakiem dojrzałości, oznacza samodzielne podejmowanie decyzji i działań na własną odpowiedzialność w świetle uniwersalnych zasad etycznych. Wychowanie w duchu tych zasad jest szczególnie ważne w społeczeństwie współczesnym, w którym zaznacza się kryzys moralności zadekretowanych odgórnie norm, powszechnie i bez wyjątku obowiązujących reguł postępowania.

„Przyszłość jest interesująca dla wszystkich, ale prognozy są niebezpiecznym zajęciem" (Berger, Brix, Prisching, 2001, s. 155) — twierdzi socjolog amerykański Peter L. Berger. Według Szczepańskiego „można ekstrapolować istniejące tendencje zmian zachodzących w społeczeństwie, można ustalać skład ludności, poziom jej wykształcenia, jej rozmieszczenie w przestrzeni i inne zjawiska oraz procesy, których elementy składowe już istnieją. Można także ekstrapolować występujące zjawiska regresu pewnych stanów rzeczy czy to w ludności, gospodarce, polityce, kulturze. Najtrudniej jednak jest przewidywać nagłe mutacje, nagłe zwroty w przebiegu zjawisk, pojawianie się nowych sposobów działania i myślenia" (Szczepański, 1999b, s. 165).

Można wyraźnie próbować wskazywać na pewne rekomendacje wychowawcze ważne dla przyszłości. Dzisiaj — także z socjologicznego punktu widzenia ważne jest pytanie nie tyle, jak możliwe jest społeczeństwo, lecz jak należy budować dobre społeczeństwo. Porządek społeczny nie utrzyma się bez wartości moralnych, a moralność nie da się zastąpić mechanizmami rynkowymi. Moralności nie da się uzasadnić ekonomicznie. W polu widzenia dzisiaj stoi przede wszystkim godność osoby ludzkiej i związane z nią wartości, jak wolność, sprawiedliwość, prawda, solidarność, uczciwość itp. Moralność ma zawsze w sobie coś z uniwersalizmu, a kompetencje etyczne obywateli są niezbędne dla budowania dobrego społeczeństwa, także społeczeństwa obywatelskiego.

Ważne jest, by przekonać ludzi, że ich decyzje i wybory powinny orientować się na wartości, choćby nie zawsze były to wartości z najwyższej półki. Jeżeli każdy jest odpowiedzialny za kształt własnego życia, to musi poczuwać się do obowiązku uczynienia z niego czegoś sensownego. W świecie o rozchwianych wartościach trudno jest znaleźć wartości sensotwórcze. Warunkiem sensownego życia są jednak trwałe wartości. Jeżeli ich byt zależy od autonomii jednostki albo są one zawsze wytworem społeczeństwa (Bauman, 2001, s. 31), wówczas muszą być one ze swej istoty zmienne i nietrwałe. Z trudem będą gwarantować sens ludzkiego życia. Ważne jest także zachowanie trwałości ładu moralnego 
w warunkach szybkich i radykalnych zmian społeczno-kulturowych (Mariański, 2005, s. 53-82).

Sytuacja moralna nie zmienia się tylko poprzez nawoływania kaznodziei, ideologów, moralistów, polityków itp., lecz także oddolnie, kiedy ludzie na przykład mają dość „dna moralnego" płynącego z egoizmu i nieuczciwości. Moralny protest może być początkiem odrodzenia moralnego. Kondycja moralna społeczeństwa nie jest dana raz na zawsze, jej poziom zależy nie tylko od tego, kto sprawuje władzę w państwie, lecz także od tego, jacy są ludzie, jakie są ich intencje i inicjatywy oraz konkretne działania. Postawy i zachowania każdego człowieka składają się na treść moralną społeczeństwa.

Upowszechniający się relatywizm — według którego wszelkie postaci moralności mają równą wartość - budzi jednak coraz wyraźniejszy sprzeciw. Nie można bowiem poradzić sobie z różnymi problemami współczesnego świata, jeżeli twierdzi się, że wszystko jest względne. Odchodzenie od normatywności, fleksybilność, akceptacja „niezwiązania”, subiektywizacja postaw, indywidualizacja zachowań ludzkich itp. zjawiska muszą mieć pewne granice, by wychowanie miało jakiś sens, a społeczeństwa mogły się ostać. Nie można oprzeć wychowania na relatywizmie poznawczym negującym możliwość ustalenia obiektywnych kryteriów prawdziwości sądów, ani na relatywizmie moralnym kwestionującym wszelkie obiektywne wartości i normy, a w konsekwencji wykluczającym moralne potępienie czegokolwiek.

\section{Bibliografia}

Baniak J., 2015: Religia i jej rola w życiu ludzi w krytycznym spojrzeniu młodzieży. Analiza socjologiczna. W: Ratio, religio, humanitas. Miscellanea dedykowane Profesorowi Zbigniewiowi Drozdowiczowi. Red. E. Jeliński, Z. Stachowski, S. Sztajer. Poznań: Wydawnictwo Naukowe Wydziału Nauk Społecznych Uniwersytetu im. Adama Mickiewicza w Poznaniu, s. 189-213.

Bauman Z., 2001: Wieczność w opałach, czyli o wyzwaniach pedagogicznych płynnej nowoczesności. „Teraźniejszość — Człowiek — Edukacja. Kwartalnik Myśli Społeczno-Pedagogicznej", nr specjalny, s. 11-32.

Berger P.L., Brix E., Prisching M., 2001: Persönliches und Gesellschaftliches. Ein Gespräch. W: Peter L. Berger und die Soziologie der Gegenwart. Gesellschaft verstehen. Hrsg. M. Pritsching. Wien: Passagen Verlag 149-163.

Kulpińska J., 2005: Jan Szczepański. W: Encyklopedia socjologii. Suplement. Red. W. Kwaśniewicz. Warszawa: Oficyna Naukowa, s. 329-334.

Kwieciński Z., 2004: Edukacja jako nadzieja wobec zagrożeń wspótczesności. „Keryks. Międzynarodowy Przegląd Katechetyczno-Pedagogicznoreligijny”, t. 3, nr 1, s. $145-158$.

Leclercq J., 1964: Katolicy i wolność myśli. Przeł. J. Prokop. Kraków: Wydawnictwo Znak. 
Lindenberg G., 1991: Studenci Warszawy po upływie ćwierćwiecza. W: Studenci Warszawy. Studium długofalowych przemian postaw $i$ wartości. Red. S. Nowak. Warszawa: Wydawnictwa Uniwersytetu Warszawskiego, s. 507-536.

Mariański J., 1990: Moralność w procesie przemian. Szkice socjologiczne. Warszawa: Instytut Wydawniczy Pax.

Mariański J., 2005: Między rajem a apokalipsa. O potrzebie wychowania ku wartościom uniwersalnym. W: Wychowanie. Pojęcia, procesy, konteksty. T. 2. Red. M. Dudzikowa, M. Czerepaniak-Walczak. Sopot: Wydawnictwo Psychologiczne, s. 53-82.

Mariański J., 2008a: Religia a wartości uniwersalne. W: Uniwersalia w międzynarodowym porównaniu. Studium polsko-niemieckie. Red. E. Dubas, H.M. Griese, M. Dzięgielewska. Łódź: Wydawnictwo Uniwersytetu Łódzkiego, s. 33-43.

Mariański J., 2008b: Społeczeństwo i moralność. Studia z katolickiej nauki społecznej i socjologii moralności. Tarnów: Wydawnictwo Diecezji Tarnowskiej Biblos.

Mariański J., 2018a: Sens życia i cierpienia w ujęciu socjologicznym w nawiązaniu do myśli Jana Szczepańskiego. W: Spotkania filozoficzno-socjologiczne na pograniczu w ramach Polsko-Czeskiej Wolnej Szkoty Nauk Filozoficznych i Społecznych im. Profesora Jana Szczepańskiego. Red. A. Kasperek, H. Böhm. Katowice: Polska Akademia Nauk Oddział w Katowicach, Stowarzyszenie Rozwoju i Współpracy Regionalnej „Olza”, s. 79—85.

Mariański J., 2018b: Wartości prospołeczne i egoistyczne w świadomości maturzystów puławskich (1994-2009-2016). „Zeszyty Naukowe WSNS”, nr 1, s. 55-74.

Prof. Jan Szczepański, socjolog, 1986. W: O kondycję moralną społeczeństwa. Materiaty ze spotkania Przewodniczacego Rady Państwa z przedstawicielami środowisk opiniotwórczych oraz działaczami społecznymi i państwowymi 7 kwietnia 1986. Warszawa: Spółdzielnia Wydawnicza „Czytelnik”, s. 242-247.

Rosińska A.M., 2007: Jana Szczepańskiego koncepcja dobrego życia. Lublin: Wyższa Szkoła Nauk Społecznych z siedzibą w Lublinie (mps pracy licencjackiej).

Sufin Z., 2005: Promieniująca indywidualność. W: J. Szczepański: Humanista - uczony - państwowiec. Księga wspomnień. Red. J. Kulpińska. Warszawa: Wydawnictwo Sejmowe, s. $253-256$.

Szczepański J., 1969: Filozoficzna i socjologiczna koncepcja człowieka. „Studia Filozoficzne", nr 1, s. 15-22.

Szczepański J., 1970: Elementarne pojęcia socjologii. Warszawa: Państwowe Wydawnictwo Naukowe.

Szczepański J., 1971: Rozważania o Rzeczypospolitej. Warszawa: Państwowy Instytut Wydawniczy.

Szczepański J., 1980: Moralność życia publicznego. „Człowiek w pracy i w osiedlu. Biuletyn TWWP", r. 19, nr 5-6, s. 7-15.

Szczepański J., 1982: Wartość działania. W: Człowiek i świat wartości. Red. J. Lipiec. Kraków: Krajowa Agencja Wydawnicza, s. 337-345.

Szczepański J., 1984a: Sprawy ludzkie. Warszawa: Czytelnik.

Szczepański, 1984b: Świat ludzkich wartości. Z socjologiem, prof. Janem Szczepańskim rozmawiaja Joanna Konieczna i Andrzej Wieluński. „Prawo i Życie”, nr 44, s. 3-4.

Szczepański J., 1986a: Dyskusje o szkolnictwie. „Odrodzenie. Tygodnik Patriotycznego Ruchu Odrodzenia Narodowego", r. 3, nr 5, s. 5.

Szczepański J., 1986b: O pracy. „Odra”, nr 11, s. 6-7.

Szczepański J., 1986c: Zapytaj samego siebie. Warszawa: Nasza Księgarnia.

Szczepański J., 1987a: Od diagnoz do działania. Warszawa: Redakcja Publikacji Wydziału Ideologicznego KC PZPR. Wydawnictwo „Książka i Wiedza”. 
Szczepański J., 1987b: Od diagnoz do działania. „Rada Narodowa” z dnia 3 VIII (Wydanie specjalne, 3 ).

Szczepański J., 1987c: Rozmowy z dniem wczorajszym. Warszawa: Krajowa Agencja Wydawnicza.

Szczepański J., 1987d: Tworzyć lepszy świat. „Tygodnik Kulturalny”, r. 31, nr 42, s. 3.

Szczepański J., 1988: O indywidualności. Warszawa: Instytut Wydawniczy Związków Zawodowych.

Szczepański J., 1989a: Polska wobec wyzwań przyszłości. Warszawa: Wydział Geografii i Studiów Regionalnych UW.

Szczepański J., 1989b: Próba prognozy. „Przekrój”, nr 2279, s. 4-5, 17.

Szczepański J., 1992a: Człowiek w strukturach zła. „Ethos”, r. 5, nr 1 s. 66-76.

Szczepański J., 1992b: Polska lokalna. W: Społeczeństwo i gospodarka w Polsce lokalnej. Red. B. Jałowiecki. Warszawa: Europejski Instytut Rozwoju Regionalnego i Lokalnego. Warszawa, s. 11-108.

Szczepański J., 1993: Polskie losy. Warszawa: Polska Oficyna Wydawnicza BGW.

Szczepański J., 1995a: Ludzie i instytucje. Powstawanie ustroju Polski Ludowej i przeksztatcenia społeczeństwa polskiego. W: Ludzie i instytucje. Stawanie się ładu społecznego. Pamiętnik IX Ogólnopolskiego Zjazdu Socjologicznego Lublin, 27-30 VI 1994. Red. A. Sułek, J. Styk, we współpracy I. Machaj. Lublin: Wydawnictwo Uniwersytetu Marii Curie-Skłodowskiej, s. 16-22.

Szczepański J., 1995b: Wizje naszego życia. Warszawa: Wydawnictwo Prywatnej Wyższej Szkoły Businessu i Administracji.

Szczepański J., 1999a: Fantazje na temat czasu. Lublin: Wydawnictwo Towarzystwa Naukowego KUL.

Szczepański J., 1999b: Najważniejsze i najtrudniejsze. Warszawa: Warszawska Drukarnia Naukowa PAN.

Szlendak T., 2004: Supermarketyzacja. Religia i obyczaje seksualne młodzieży w kulturze konsumpcyjnej. Wrocław: Wydawnictwo Uniwersytetu Wrocławskiego.

Sztompka P., 2017: Społeczeństwo dzieje się pomiędzy. „Więź”, nr 1, s. 94-105.

Wargacki S.A., 2015: Socjologia zła. W: Leksykon socjologii moralności. Podstawy teorie - badania perspektywy. Red. J. Mariański. Kraków: Zakład Wydawniczy NOMOS, s. $758-761$. 